\title{
PERAN ELITE SUKU TENGGER DALAM PEMILU 2019 DI DESA ARGOSARI KECAMATAN SENDURO KABUPATEN LUMAJANG
}

\author{
Muhammad Kemal Mubarok ${ }^{1}$, Priyatmoko ${ }^{2}$ \\ ${ }^{1}$ Departemen Ilmu Politik, Fakultas Ilmu Sosial dan Ilmu Politik, Universitas Airlangga \\ kemalmubarok27@gmail.com \\ ${ }^{2}$ Departemen Ilmu Politik, Fakultas Ilmu Sosial dan Ilmu Politik, Universitas Airlangga \\ priyatmoko@fisip.unair.ac.id
}

\begin{abstract}
This research focuses on the roles of the elite in the Tengger Tribe in the last 2019 elections, more precisely discussing matters related to authority and authority in the successful holding of the 2019 elections yesterday. This elite which is divided into several segments is a channel for the aspirations of the lower classes. The minimal knowledge of the Tengger Tribe regarding politics and government makes some actions and choices tend to follow the local elites. In this case, the elite in the eyes of Max Weber, dividing it into three types according to social relations. The three types are traditional authority types which in Tengger society are occupied by adat pandhita shamans, charismatic authority types which are occupied by Hindu religious leaders and Islamic religious leaders, and the last is formal legal authority type occupied by the Argosari village head. Concerning the 2019 General Elections, each has its own mass base in terms of the type of authority. Even though the village head, traditional shaman, Muslim and Hindu community leaders, do differ in their political choices, they still uphold democratic values along with their traditional values. Some philosophies related to democracy and elections according to the elite and the Tengger community are the same as the life guidelines handed down from their ancestors. Tengger Tribe living guidelines include, among others, Tenggering benevolence, Sesanti Titi Luhur, Disathru, and Hila-Hila which are instructions for democracy. The implementation of elections and democracy in peace will be realized when the Tengger Tribe people follow the guidelines of their ancestors. Thus, the motto adopted by the local community can be realized "Memayu Hayuning Bawono and Sepi Ing Pamrih Rame Ing Gawe".
\end{abstract}

Keywords: Role of elite, 2019 concurrent elections, democracy, Tengger Lumajang Tribe, authority.

\section{PENDAHULUAN}

Indonesia adalah negara yang memiliki keanekaragaman budaya. Kekayaan budaya menjadi ciri khas Indonesia yang melekat dalam jati dirinya. Hal ini tentu memiliki pengaruh terhadap kehidupan berbangsa dan bernegara pada masyarakat. Semboyan Bhineka Tunggal lantas relevan untuk meneguhkan pandangan masyarakat untuk bersatu dalam keberagaman. Dalam konteks politik, keberagaman di tengah masyarakat seringkali menjadi pemicu konflik.

Suku Tengger atau disebut juga Wong Tengger atau Wong Brama adalah suku yang mendiami dataran tinggi di kawasan Pengunungan Bromo-Tengger-Semeru. Lokasi dari pegunungan ini berada di Provinsi Jawa Timur. Secara umum, kawasan ini berada di sebagian wilayah Pasuruan, Lumajang, Probolinggo, dan Malang. Orang Tengger dikenal sebagai orang-orang yang taat dengan aturan dan agama Hindu. Penduduk Tengger juga diyakini sebagai keturunan langsung dari Kerajaan Majapahit. Dalam sebuah penelitian yang dilakukan oleh Robert W Hefiner, dijelaskan bahwa Suku Tengger memiliki karakteristik kebudayaan. Hal ini ditandai dengan setidaknya lima indikator. Pertama, bahwa masyarakat Tengger menggunakan Bahasa Jawa Kuno. Bahasa tersebut diyakini sebagai dialek pada masa Kerajaan Majapahit. Kedua, perkembangan teknologi memang sudah berkembang di masyarakat. Hal ini tidak terlepas dari kedatangan wisatawan domestik dan para pendatang baru. 
Ketiga, masyarakat Tengger memang memeluk agama Hindu, tetapi ada perbedaan dengan Hindu di Bali. Masyarakat Tengger memeluk Hindu Mahayana, sedangkan masyarakat Bali memeluk Hindu Dharma. Keempat, mata pencaharian masyarakat Tengger kebanyakan adalah bertani di ladang. Hasil dari pertaniannya adalah kubis. Selain sebagai petani, mata pencaharian masyarakat Tengger sebagian adalah pemandu wisata.

Pekerjaan masyarakat yang dominan sebagai petani, tinggal di pegunungan, dan memeluk agama Hindu tentu membentuk budaya politik yang khas. Masyarakat Tengger, seperti dikatakan Hefiner, memiliki historiografi sejarah yang panjang. Tengger dikenal memiliki keteguhan dalam mempertahankan nilai-nilai, tradisi, dan kebudayaan di tengah arus perubahan zaman.

Dalam kehidupan beragama, masyarakat Tengger dikenal memiliki prinsip. Seorang pemuka masyarakat Tengger bernama Wirnoto menjelaskan bahwa ketika ditanya oleh Bupati Ishak, apakah agama atau keyakinan orang Tengger. Kebanyakan kepala desa dan pemuka desa menyatakan bahwa agama atau keyakinan orang Tengger adalah Budo. Kemudian beberapa dari mereka menjelaskan bahwa agama Budo telah ada sejak zaman nenek moyang.

Dalam konteks politik pasca peristiwa 1965, masyarakat Tengger juga terdampak. Dalam catatan yang dituliskan oleh Hefner (1990), kanal-kanal di Pasuruan banyak sekali ditemukan jasad orang Tengger. Kejadian ini menjadi trauma banyak pihak secara nasional. Akibat tragedi berdarah itu, ada trauma yang mendalam dari orang Tengger. Label kafir dan komunis telah menjadi momok baru dalam kehidupan mereka. Beragam cara mereka tempuh untuk terhindar dari stigma itu. Salah satu yang mereka lakukan adalah menjalankan ritual khitanan. Hal ini tidak terlepas dari stigma kafir oleh orang-orang Ngare karena tidak melakukan sunat sehingga orang Tengger menjalankan praktik sunat. Kendati demikian, pengaruh sejarah yang mempengaruhi budaya politik masyarakat Tengger. Setidaknya ada tiga peristiwa sebagaimana dimaksud menurut Heffner. Pertama, masyarakat Tengger adalah entitas kelompok Hindu yang melarikan diri dari Majapahit di era keruntuhan kerajaan tersebut karena pengaruh dari dominasi kekuasaan islam. Kedua, persoalan mengenai pelabelan komunis di era Orba paska peristiwa 1996. Ketiga, persoalan mengenai formalisasi agama dengan menyandarkan PNPS Nomor 1 tahun 1965 mengenai kebijakan pengakuan agama oleh negara.

Dampak sejarah terhadap peta politik masyarakat Tengger menjadi fokus penelitian ini. Fakta sejarah yang tertuang dalam karya Heffner, bahwa formalisasi masyarakat Tengger yang memiliki bobot masalah terhadap komunis dan keyakinan agama yang sebenarnya. Dalam konteks politik, faktor sejarah dan agama memiliki pengaruh. Kehadiran Islam disatu sisi, dan dominasi kekuasaan pemerintah di sisi lain, mengubah banyak hal dalam sistem kehidupan masyarakat Tengger.

Ali Maksum (2015) Penjelaskan mengenai masyarakat Tengger memilih untuk melakukan negosiasi terhadap pengaruh dari luar tersebut adalah hal wajar. Hal ini dilakukan dengan menerima formalisasi agama di satu sisi. Sisi lain, adalah menerima agama formal tersebut secara simbolik. Selain itu menurut Ali Maksum, masyarakat Tengger menolak praktek agama yang bertentangan dengan ritual adat. Instrumen politik untuk mempertahankan adat masyarakat Tengger pun dilakukan 
secara politik. Pertama, melalui keberadaan program pariwisata. Program yang dimaksudkan untuk menarik minat wisatawan ini, secara langsung sebenarnya sangat membantu masyarakat Tengger untuk mempertahankan budaya khasnya. Baik secara ritus adat, maupun dalam tatanan masyarakat. Kedua melalui pengangkatan tokoh nasional dan daerah yang ditunjuk untuk menjadi sosok atau sesepuh Tengger. Dalam setiap bulan Kasada, orang Tengger mengundang dan meminta tokoh dari pemerintahan, anggota DPR untuk menjadi sesepuh Tengger. Ketiga yakni membangun mitos dan mitologi di tengah kehidupan masyarakat.

Secara sosial budaya terdapat peristiwa larangan berdirinya musholla/ masjid di Desa Gedog oleh kepala desa. Peristiwa ini terjadi sekitar tahun 2011-an. Terjadinya peristiwa ini tidak terlepas dari latar belakang agama kepala desa yang beragama Hindu dan mayoritas masyarakat Dusun Argosari yang beragama Hindu pula. Pelarangan lainya juga terjadi pada larangan masyarakat muslim Suku Tengger untuk mengikuti upacara adat Karo oleh kepala desa. Dan hal ini pun juga tidak terlepas dari latar belakang kepala desa yang beragama Hindu serta mayoritas masyarakat yang beraga Hindu.

Peristiwa yang ketiga, terkait pemilihan kepala desa (Pilkades) yang terdiri empat (4) calon, dimana tiga diantaranya merupakan calon kepala desa beragama hindu, dan satu calon beragama Islam. Hal ini juga menggambarakan kondisi sosial Desa Argosari, Kecamatan Senduro, Kabupaten Lumajang. Terpilihnya Pak Ismail sebagai kepala desa tak terlepas dari latar belakang beliau yang juga beragama Hindu totok serta dukungan dari mayoritas masyarakat yang beragama Hindu pula. Hal ini pula yang membuat peneliti tertarik untuk menguji terkiat aspek sosial budaya mempengaruhi peran elite dalam pemilu 2019.

Menjadi menarik kemudian, ketika kondisi masyarakat Tengger dalam perspektif sejarah dan budaya mengungkapkan adanya karakter khas masyarakat adat tersebut, jika dihadapkan dengan hiruk pikuk pesta demokrasi. Pesta demokrasi dalam hal ini adalah Pemilihan Umum (Pemilu). Peran elite lokal kemudian dipertanyakan dalam konteks memilih partai politik yang ada saat ini. Selain itu, isu soal kesamaan suku, dan keyakinan kemudian memiliki bobot tersendiri untuk diteliti lebih dalam. Berbicara terkait masyarakat Tengger, terdapat hal unik berupa bagaimana prosesi pengangkatan dukun adat sebagai tokoh panutan atau tetua masyarakat adat. Terkait proses pengangkatan ini diselenggarakan saat upacara atau ritual adat Yadnya Kasada, dimana beberapa dukun adat yang mau dilantik dan diangkat harus mengetahui dan hafal terhadap mantra-mantra yang nantinya dibaca. Perihal mantra-mantra disini merupakan mantra yang turun temurun dilestarikan yang juga berasal dari nenek moyang serta roh leluhur masyarakat Suku Tengger. Jauh dari upacara tersebut, penobatan dukun, dilakukan dengan cara musayawarah mufakat melalui seleksi serta ditinjau beberapa persyaratan yang ditentukan secara pakem oleh leluhur mereka terdahulu.

Pada tahun 2019 lalu, masyarakat Tengger yang berada di wilayah administratif Kabupaten Lumajang turut memberikan hak suara yang diberikanya melaui bilik-bilik suara pada tiap TPS yang ada. Salah satu desa yang termasuk secara admisitratif wilayah Kabupaten Lumajang adalah Desa Argosari Kecamatan Senduro. Kecamatan Senduro disini berletak di sebelah barat Kabupaten 
Lumajang, kurang lebih $17 \mathrm{Km}$ dari pusat kota. Kecamatan senduro merupakan daerah pegunungan yang terletak di ketinggian mulai $100-2.000 \mathrm{~m}$ dari permukaan laut. Senduro merupakan jalur pendakian menuju Gunung Semeru melalui Lumajang. Penduduk desa yang berada di kawasan Gunung Bromo ini mayoritas bersuku Tengger dan beragama Hindu, kecuali di Dusun Gedok yang mayoritas beragama islam.

Di desa argosari sendiri terdapat empat Dusun antara lain, Dusun Bakalan, Dusun Pusung duwur, Dusun Gedog, dan Dusun Argosari yangmana ke empat dusun ini memiliki keterkaitan panjang terhadap sejarah Tengger. Dalam kehidupan bermasyarakat yang kompleks ini pastilah terdapat sutuasi serta kondisi yang kompleks pula, tak terkecuali proses politiknya, yang mana dalam penerapanya melibatkan banyak orang, kaitanya suku tengger disini melibatkan elite dan massa. Proses politik dan kehidupan berpolitik suku tenger dapat dilihat melalui proses hingga akhir hasil pemilu. Dimana begitu banyak faktor yang dapat digali guna khasanah ilmu pengetahuan. Salah satunya dari elite yang berperan dalam percaturan politik ini. Salah satu elite yang ada, Kepala desa contohnya, yang merupakan kepala administatif formal desa Argosari letak suku tengger berada, tugas serta kekuasaan Kepala Desa ini mencakup keseluruhan aspek administratif Desa Argosari. Adapula tokoh masyarakat Hindu, tokoh masyarakat Islam, tokoh adat Tengger, pengusaha, preman, dan banyak patron lainya yang turut terlibat.

Dalam segi demokrasi terkait pilihan serta proses politik, masyarakat Tengger dinilai telah dewasa menanggapinya, hal ini tertera dalam berbagai media yang menceritakan terkait pemilu yang diadakan 17 April 2019 lalu tentang renak-renik Suku Tengger. Dari segi penyambutan pesta demokrasi itu sendiri, masyarakat Suku Tengger merasa senang serta bahagia dan terkesan seperti kedatangan tamu agung yang harus dijamu dan dilayani dengan baik. Sehingga, masyarakat Tengger berbondong-bondong mengikuti dan turut andil didalamnya.

Seperti yang dilansir dalam pemberitaan media Probolinggo, pada Sabtu, 23 Maret 2019 lalu, terkait bagaimana masyarakat Tengger menyongsong tinggi nilai-nilai demokrasi dan turut serta suksesi terhadap acara agung bangsa ini yaitu Pemilu serentak. Masyarakat Tengger yang dikenal sebagai suku adat yang tetap solid menjaga kelestarian roh leluhurnya ini juga solid pula dalam acara kebangsaan dan kenegaraan. Sehingga tak dipungkiri jiwa nasionlisme masyarakat Tengger tak dapat diragukan lagi.

Hasil dari kesolidan dan kekompkan serta nilai luhur yang dipercaya oleh masyarakat Tengger, hal ini membuat lembaga penyelenggara Pemilu, dalam hal ini Komisi Pemilihan Umum (KPU) membuat beberapa istilah dalam mengantisipasi problema yang ada dan selalu mengiringi terjadinya proses pemilu ini dengan menggunakan istilah-istilah dari filosofi yang dianut oleh masyarakat Tengger, yang memiliki makna dan harapan besar guna terselenggaranya acara demokrasi Indonesia dengan baik dan terbebas dari perpecahan. Dalam pemberitaan tersebut, sedikitnya terdapat sepuluh filosofi adat Tengger yang menjadi acuan dalam bertindak oleh KPU. 
Bagi masyarakat Tengger, datangnya pesta demokrasi tiap lima tahunan ini adalah untuk memilih seorang pemimpin yang kerja nyata bukan hanya sekedar janji-janji saat kampanye belaka. Bagi masyarakat Tengger peran elite dalam perpolitikan yang ada dalam masyarakat juga cukup besar, namun dalam hal ini tidak membuat masyarakat Tengger terkotak-kotak karena perbedaan dukungan dan mendukung salah satu peserta pemilu. Beberapa elit yang disuku Tengger, memberi arahan serta masukan berupa pelajaran dimana para pemangku kepentingan pada pemilu 2019, khususnya elit-elit nasional hendaknya mengambil banyak pelajaran dari masyarakat suku Tengger. Masyarakat Tengger memberikan pelajaran bahwasanya kepemimpinan itu bukan hanya soal kekuasaan dan memenangkan kontestasi pada pesta demokrasi, namun lebih dari itu, ialah bagaiaman upaya untuk memenuhi kebutuhan sosok pemimpin yang terbaik bagi masyarakat Indonesia.

Penelitian ini dibuat untuk sebagai pelengkap penelitian terdahulu yang hanya membahas menggunakan teori kebudayaan serta politik identitas. Namun, dalam penelitian ini peneliti ingin meninjau melalui teori elite milik Max Weber yang mencakup tipe-tipe hubungan dalam hal otoritas yang dimiliki tiap-tiap elite pada konteks kepemiluan. Dalam penelitian yang disajikan ini, peneliti ingin berkontribusi terkait dalam bentuk penambahan literasi serta bahan kajian mengenai peran elite serta kepemiluan pada masyarakat, khusunya tentang masyarakat adat.

Data dala penelitian ini diperoleh melalui analisis isi berita serta wawancara dengan beberapa narasumber yang berkaitan dengan peran serta elite Suku Tengger dalam pemilu 2019 di Desa Argosari. Metode yang digunakan dalam penelitian ini ialah metode kualitatif deskriptif dengan menggambarkan keadaany sesungguhnya yang terjadi dengan menghubungkanya dengan teori elite Max Weber.

\section{PERAN ELITE TENGGER DALAM PEMILU}

Desa Argosari melibatkan beberapa elite yang turut mensukseskan terselenggaranya Pemilihan Umum 2019 lalu. Dari elite formal maupun non-formal menjalankan tugas sesuai dengan wewenang serta kemampuannya masing-masing. Dari elite formal terdiri dari Kepala desa. Sedangkan elite non-formal terdiri dari dukun adat, pengusaha, dan beberapa tokoh masyarakat yang berlatar belakang agama.

Dukun adat memiliki kekuasaan yang lebih independen daripada kepala kampung atau kepala desa. Sehingga dimasa lampau dukun adat ini mirip seperti "raja kecil" dalam suatu sistem pemerintahan yan tertutup. Mereka sendiri umumnya bertindak sebagai pemimpin politik, adat, sosial, serta pemimpin dalam hal kebudayaan. Dan hal ini juga mencakup bagaimana menjalin hubungan antara segala segmen dan bagian-bagian di daearah desa sekitar.

Dalam proses terpilihnya dukun adat disini, terdapat beberapa metode dalam penentuan pengangkatanya, pertama secara garis keturunan atau diwariskan dari nenek-moyangnya dari kakek dan bapaknya. Yang kedua dipilih secara demokratis oleh seluruh anggota suku atau dipilih atas saran anggota suku atau juga bisa dipilih oleh tetua-tetua adat suku tersebut. Yang terakir proses 
pengangktan dan pemilihannya melalui suatu perlombaan dan sayembara. Perlombaan atau sayembara tersebut berabagai macam bentuknya, ada yang tentang adu kesaktian, adu kekuatan atau keberanian, ataupun hal lain yang dianggap cocok sebagai seorang dukun adat.

Pak karyoleh sebagai dukun adat termuda, dipilih dan diangkat secara adat. Proses pengankatan ini dilakukan saat acara kasada. Dengan diangkatnya pak karyoleh sebagai dukun adat menandakan kelengkapan secara keseluruhanya. Yang pakem tiga belas dukun adat desa Argosari, kemudian dengan meninggalnya kakak pak Karyoleh (Pak Sutarco) posisi dukun adat hanya dua belas orang. Dan saat ini kembali lagi di posisi tiga belas dukun adat. Proses pengangkatan Pak Karyoleh selaku dukun adat adalah saat acara adat Kasada, dimana dalam acara tersebut dibacakan pula mantramantra yang sudah turun-temurun abadi dari nenek moyangnya.

Seorang panutan Tengger yang umurnya kurang lebih setengah abad ini merupakan salah satu dari 13 sosok dukun adat suku Tengger yang merupakan keturunan ke 11 dari keluarganya. Dalam hasil penjajakan serta banyaknya informan yang peneliti wawancarai, beliau merupakan dukun adat termuda dan paling di tokohkan serta memiliki pengetahuan yang cukup luas. Keilmuan beliau serta pemahaman beliau baik dalam unsur adat serta birokrasi membawa Pak Karyoleh sering diundang oleh pemerintah kota lumajang sebagai wakil dari suku Tengger di Lumajang khususnya Desa Argosari. Menurut pak Karyoleh jabatan yang disandangnya merupakan jabatan yang berat dimana memiliki pertanggung jawaban yang besar nantinya kepada Tuhan. Merawat solidaritas umat, menjaga tali asih, dan yang paling pokok ialah pelaksana ritual adat. Dalam tata laku kehidupan pak Karyoleh memiliki beberapa nilai-nilai luhur yang menjadi pedoman hidupnya. Seperti "Memayu Hayuning Bawono" yang mana filosofi jawa ini bermakna memperindah lingkungan. Dalam spiritualitas budaya dan kegamaan kita layaknya manusia yang diturunkan di muka bumi ini harus menghayati laku batin dan senantiasa menghiasi pernak-pernik kesejahteraan di dunia.

Filosofi yang kedua adalah, "Sepi Ing Pamrih Rame Ing Gawe" yang bermakna tidak mengharapkan pamrih, giat serta sungguh-sungguh dalam bekerja. Sehingga dalam melakukan suatu hal hendakanya kita sebagai manusia seutuhnya jangan terlalu berharap dan memikirkan apa yang akan kita dapat, serta tak perlu banyak bicara. Makna ini tersirat dalam tata laku pak Karyoleh yang bijak dalam beberapa hal seperti mengayomi masyarakat desa adat suku Tengger.

Dukun adat Suku tengger di desa Argosari ini, juga berperan menyambut dan meberikan tanda kehormatan kepada tamu spesial yang datang ke desa Argosari. Tamu-tamu spesial tersebut diberikan tanda kehormatan dengan sebutan "warga kehormatan" guna turut melestarikan budya serta mengawal berjalanya acara ritual adat mereka. Pejabat publik, elite politik, petinggi aparatur negara, serta orang berpengaruh lainya yang merupakaan contoh-contoh tamu kehormatan masyarakat suku tengger di desa Argosari.

Dalam kaitanya tentang proses demokrasi dimana dilaksakan pula Pemilu di desa ini. Dukun adat yang meruapakan tetua adat suku Tengger yang berada di Desa Argosari ini memiliki beberapa peran guna suksesi pemilu. peran-peran ini digambarkan konsistensinya melalui apa yang 
disumpahkan kepadanya atas janji-janji kerohaniawan. Peran Pak Karyoleh sebagai dukun Adat Suku Tengger ini antara lain menerima dan mengenalkan calon yang datang kepadanya. Namun hal ini bukan berarti turut mensosialisasikan dukungan guna penggalangan suara dan massa untuk memilih salah satu kandidat calon. Melainkan hal ini sebagai bentuk bantuan informasi kepada khalayak masyarakat Suku Tengger Desa Argosari, bahwa di daerah tersebut terdapat beberapa kandidat.

Peran dukun adat dalam pemilu juga tersirat dari ucapan dan perilaku pak Karyoleh. Dimana beliau menyebutkn politik saat ini bukan lagi menunjukkan politik yang berbudaya melainkan sudah terjurumus kepada budaya politik. Sehingga dengan demikian pak Karyoleh juga selalu memberi informasi nilai-nilai normatif guna memahamkan masyarakat Suku Tengger Desa Argosari.

Semua calon yang datang, Pak Karyoleh turut mendoakan dan merestui. Namun hanya sebatas itu saja dan tidak boleh masuk terlalu dalam seperti dukungan kepada calon-calon yang ada. Maksud dari doa dan restu yang dipanjatkan kepada mereka ialah agar mereka dapat amanah dan dipilih sesuai dengan harapan masyarakat Suku Tengger Desa Argosari. Maksud dukun adat tidak mengarahkan dan menggalang massa, hal ini guna mengayomi keseluruhan masyarakat yang ada. Sehingga dengan datangnya Pemilu dukun adat sebatas menjadi wasit yang turut memantau jalanya pemilu yang damai. Semua ini dilakuakan sesuai dengan kesepakatan dan sumpah yang ada.

Berbeda dengan kepala desa dalam hal ini Sesuai dalam Peraturan Menteri Dalam Negeri Republik Indonesia Nomor 84 Tahun 2015 Tentang Struktur Organisasi dan Tata Kerja Pemerintah Desa, Kepala Desa adalah pejabat Pemerintah Desa yang mempunyai wewenang, tugas dan kewajiban untuk menyelenggarakan rumah di desanya serta sebagai pelaksana tugas dan kepanjangan tangan dari pemerintah dan pemerintah daerah. Kepala desa memiliki masa jabatan 6 tahun, dimana jabatan ini dapat diperpanjang selama 3 kali, secara berturut-turut atau tidak. Sama halnya dengan desa-desa lain di Indonesia, Pak Ismail sebagai Kepala Desa juga bertanggung jawab atas penyelenggaraan Pemerintahan Desa, pelaksanakan Pembangunan Desa, pembinaan kemasyarakatan Desa, dan pemberdayaan masyarakat Desa.

Pak ismail sebagai kepala desa yang mengatur keseluruhan rumah tangga desa Argosari juga cerdas dalam mengkombinasikan antara adat dan pemerintahan. Meskipun Pak Ismail meruapakan salah satu orang terpandang di Desa Argosari, namun tetap membawa nilai luhur adatnya. Beliau menganggap tugas yang diembanya sekarang juga tidak mudah, sehingga bukan hanya tentang bagaimana menajadikan desa Argosari sejahtera sekalian juga terkait bagaimana mensejahterakan dan mensukseskan acara yang terlahir dari nilai luhur adat suku Tengger. Segala permasalahan desa seperti pada umunya masyarakat suku tengger dijamu di dapur rumah, pak Ismail menyelesaikan pekerjaan desa, seperti rapat koordinasi beserta jajaranya, kumpul bersama dukun adat, serta komunikasi dengan warganya.

Kepala Desa Argosari yang merupakan salah satu anggota suku tengger ini juga berkewajiban mensukseskan acara-acara adat, walaupun tidak tertulis secara formal dalam pokok tugas pekerjaan kepala desa. Namun, hal ini merupakan kesadaran serta salah satu nilai luhur yang wajib digotong 
bersama tanpa memandang status sosial yang ada. Mensinergikan adat dengan pemerintah desa juga suatu hal yang lumrah dilakukan oleh beliau.

Sesuai dengan hak dan kewajiban adminisratifnya, kepala desa turut berperan pula guna memahamkan masyarakat tentang pengetahuan agar turut serta dalam proses berdemokrasi. Hal ini didasarkan karena minimnya tingkat pendidikan masyarakat desa setempat terhadap Pemilu. Sehingga dengan demikian masyarakat desa Argosari ini mampu menjalani kegiatan lima tahunan pemilu ini dengan benar, sesuai dengan peraturan dan norma yang ada. Dengan adanya momen ini, kepala desa pun tururt melakukan penyuluhan serta sosialisasi hal-hal terkait.

Selain mensosialisasikan terkat kepemiluan, Kepala Desa juga juga seringkali didatangi dan dimintai dukunganya terhadap beberapa calon dan kandidat. Ada yang diwakilkan oleh tim suksesnya, ada juga yang datang langsung menemui Pak kepala desa. Nah dari sinilah biasanya kepala desa dapat memetakan dan mengarahkan kemana calon yang datang di mencari suara atau konsituen. Hal ini tentulah bukan sembarangan arahan. Melainkan dengan adanya pemantauan berdasarkan kondisi masyarakat, agama, budaya, letak geografis dan lain-lain.

Lain halnya dengan elite muslim setempat, yang mana disebutkan Islam sebagai salah satu agama masyarakat Tengger di Desa Argosari memberikan sedikit perbedaaan dari keumuman masyarakat suku Tengger yang beragama Hindu. Sebagai seorang yang dituakan dan beragama Islam, Pak Sandoyo memiliki pengaruh bagi masyarakat muslim di desa Argosari. Dalam acara-acara keagamaan seperti Sholawatan, Diba'an, Mauludan, serta acara adat islam jawa lainya Pak Sandoyo selalu hadir di tengah tengah masyarakat dan mengawal jalanya acara. Selain acara-acara keagamaan, Pak sandoyo juga seringkali menanmkan nilai-nilai kebersamaan dan gotong royong antar warga. Sikap saling membantu ini diperolehnya dari ajaran nenek moyangnya. Hal ini dapat dilihat dari bagaimana pak Sandoyo memimpin antar warga sekitar untuk bahu-membahu melaksanakan suatu kegiatan bersama seperti membenahi rumah salah satu warga agar layak menjadi tempat tinggal. Jika ada rumah warga yang rusak atau sudah tak layak maka pak Sandoyo mengajak warga muslim lainya untuk membantu mneyelesaikan persoalan tersebut. Selain itu, sedekah bumi juga meupakan agenda tahunan suku tengger yang beragama muslim.

Dalam perwujudan pemilu yang damai, tokoh masyarakat desa Argosari juga turut membantu calon yang datang untuk melakukan sosialisasi kepada masyarakat. Hal ini dikarenakan mereka juga memiliki basis masa yang lumayan besar di belakangnya. Ada yang dari kalanagan anak muda, anggota fatayat, muslimat, remaja masjid, hingga anggota banjari. Kesemuanya ini biasanya tokoh masyarakat yang mengakomodir. Ketika calon kandidat datang, maka disinilah lahan tokoh masyarakat seperti pak Sandoyo menuntut aspirasi dan segala hal terkait kebutuhan masyarakatnya.

Dengan demikian secara sadar maupun tak sadar beberapa hal mengenai konsolidasi kepada beberapa rekan serta masyarakat sekitar untuk membantu susksesi salah satu calon yang dianggapnya mampu membawa aspirasi masyarakatnya sesuai dengan kebutuhan dan keinginan desa setempat. Sama halnya dengan masyarakat desa pada umunya. Praktik-praktik transaksi politik juga masih ada. 
Suara yang datang biasanya tidak melulu karena visi dan misinya yang baik serta figur yang berkesan di hati masyarakat. Melainkan juga karena faktor adanya suguhan, titipan, maupun sesrahan yang berguna bagi masyarakat Desa Argosari seperti pemeberian sarung, pembalut kepala atau udeng, atau juga terjadi bagi-bagi uang yang berkedok dana transport.

Elite selanjutnya ialah pemuka Agama Hindu, Hindu adalah salah satu agama yang banyak dianut oleh masyarakat suku Tengger, khusunya di Desa Argosari. Terdapat beberapa kegiatan keagamaan hindu di Desa argosari diantaranya ialah galungan, nyepi dan kegiatan ibadah lainya. Pak Repin selaku tokoh masyarakat Hindu di Argosari memaparkan bahwasanya dalam laku kehidupan serta roda pemerintahan desa layaknya masyarakat pada umumnya kita wajib memantau, menghiasi, serta mengawal keseluruhan aspek dalam desa, namun dalam hal ini tanggung jawab sepenuhnya kaitanya terkait hal-hal yang menyentuh dan berhubungan dengan masyrakat hindu pak Repin adalah termasuk orang sebagai garda terdepan. Ketika terjadi perselisihan, hubungan antar umat beragama, dan pemebritahuan terkait program serta hasil musyawarah desa elite agama inilah yang merupakan orang pertama sebagai penerus ke khalayak masyarakat Desa Argosari.

Hampir mirip dengan tokoh masyarakat islam, namun perbedaanya pada kalangan dukungan serta konsolidasinya. Dengan dipandanganya pak Repin sebagai tokoh agama Hindu yang mana mengerti dan dianggap tinggi pemahaman keagamaanya terkait Hindu membuatnya dipercaya dan dipandang lebih mengerti terkait pilihan dalam politik. Hal ini juga membuat beberapa figur partai berbondong-bondong menemuinya. Karena dengan ditemuinya pak Repin sebagai Tokoh Hindu setempat maka urusan masyarakat yang beragama Hindu di Desa Argosari terselesaikan, karena beliau merupakan simpul dalam penarikan dan penggalangan suara. Selain hal diatas, tugas pak Repin sebagai tokoh agama Hindu setempat juga turut membantu mensosialisasikan pemilu kepada masyarakat khalayak.

\section{PANDANGAN ELITE SUKU TENGGER TENTANG PEMILU DAN DEMOKRASI}

Menurut elite suku tengger masyarakat menyambut gembira atas datangnya acara 5 tahunan Pemilu. Tengger yang merupakan masyarakat tradisional mempunyai nilai-nilai luhur yang justru tak jauh berbeda dengan nilai-nilai demokrasi dalam Pemilu. hal ini terlihat dari 10 filosofi Hidup masyarakat suku Tenger yang juga diadopsi oleh KPU. Kesepuluh filosofi ini merupakan modal awal bagi terciptanya perdamaian dalam pemilu. sepuluh filosofi tersebut yang pertama adalah, "Tengering Budi Luhur" yang memilki makna bahwasanya pemilu haruslah berintegrittas dan profesional, sehingga dalam penyelenggaraanya mampu bersifat Luber dan Jurdil, kemudian ada "walandhit" bermakna dalam melayani masyarakat dalam pemilu haruslah setulus hati, penuh tanggung jawab, ikhlash, serta berlaku secara independen. Filisofi ini dapat dilihat secara langsung terkait bagaimana dukun-dukun adat masyarakat Tengger yang memegang teguh netralitas serta memberikan porsi yang sama terhaap siapapun kandidat. Selanutnya "Tengger" yang berarti siap menegakkan keadilan guna tercapainya cita-cita bangsa dan negara dimana mereka bernaggapan pemilih yang cerdas akan mampu 
menghasilkan pemimpin yang berkualitas. Selanutnya "Sesanti Titi Luhur" bermakna mencerdaskan masyarakat melalui sosialisasi dan pendidikan pemilih yang berkelanjutan, hal ini dilkukan guna terbentuk kesadaran dalam demokrasi tanpa adanya unsur paksaan dan tekann dari pihak manapun. Selanjutnya merupakan filosofi "disatru" yaitu politik uang atau pemberian lainya berlaku tidak sah dan tidak diperbolehkan. "Hilahila" yang bermakna dalam menjalankan tugasnya wajiblah "prasaja" berarti jujur apa adanya, "prayoga" berarti bijaksana, "pranata" berarti patuh terhadap peraturan, "prasetya" setia pada Pancasila dan NKRI, dan "prayitna" berintegritas dan profesional.

Filososfi ketujuh yaitu "Aja Jowal-Jawil” bermakna memiliki sikap toleransi yang tinggi terhadap orang lain, guna kerukunan, perdamaian, serta lingkungan semesta yang tentram. Hal ini dapat dibuktikan dengan prilaku masyarakat Tengger yang toleran antar agama dan menyambut baik wisatawan yang datang. Selanjutnya ajaran "Nyadhang" yang bermakna tanggung jawab dan patuh terhadap peraturan-peraturan dan hukum tertulis baik itu hukum agama, hukum adat serta hukum lainya. Selanjutnya "Tat Twam Asi serta Mikul Nduwur Mendem Njero" bermakna memiliki sikap welas asih serta wajib menunaikan janji-janji politik selama berkampanye. Dan filosofi yang terakhir adalah "Unan-unan" pagelaran acara demokrasi yang diselenggrakan 5 tahun sekali ini kita memilih eksekutif dan legislatif yang mumpuni dan paling baik-diantara lainya.

Melalui pemilu ini masyarakat suku Tengger di Desa Argosri dapat memilih siapa pemimpin selanjutnya yang dianggap mampu mengentaskan permasalahan serta membawa perubahan yang lebih baik guna kemajuan, kemandirian, dan kesejahteraan baik dalam bidang sosial, budaya serta ekonominya. Karena melalui pemilu ini proses pergantian kepemimpinan diatur lebih baik dan seluruh masyarakat dapat memilih dan menentukan secara merdeka dan mandiri pemimpin yang dianggap terbaik untuk memimpin negeri ini kedepan.

Adanya demokrasi membuat masyarakat lebih terbuka. Nilai dan prinsip demokrasi yang dibawa oleh semangat reformasi membuat kondisi traumatis masyarakat suku tengger di desa Argosari menurun. Hal ini dikarenakan saat masa kepemimpinan Soekarno yang mayoritas masyarakat suku tengger terafiliasi dengan partai Nasonalis Indoensia (PNI) dituduh sebagai simpatisan atau anggota partai komunis Indonesia (PKI) pada masa peralihan kepemimpinan soekarno ke soeharto di tahun 1965. Banyak masyarakat Tengger terbunuh (kaitanya dituduh PKI, secara traumatik).

"Masyarakat disini itu manut sama pemerintah mas, siapa yang berkuasa ya masyarakat sini ngikut. Yaa mereka trauma saja sama sejarah dulu tahun 65an, masyarakat sini banyak dibunuh karena dituduh antek PKI, banyak warga sini isunya dibuang ke sungai yang sebenanrnya mereka semua bukan warga sini mas. Mereka warga pendatang yang nunut sembunyi disini namun kita tolak. Maka dari itu kita yo juga menolak kedatangan PKI dan nurut sama pemerintah, westoh mas sing amanaman ae" (Wawancara dengan Karyoleh, dukun adat Tengger Desa Argosari Lumajang, 2019).

Demokrasi menjadikan suara masyarakat lebih dihargai, semua orang memiliki kedudukan dan hak yang sama di mata negara, yang keseluruhanya itu diatur dalam Undang-undang dasar tahun 
19945 dan hukum internasioanl. Dalam demokrasi tidak ada pembeda antara si kaya dan si miskin, si pintar dan si bodoh, ataupun perbedaan lainya. Semuanya melebur menjadi satu, menunagkan suaranya sesuai isi dari hati nuraninya. Dalam hal ini terlihat juga dalam prinsip demokrasi dan pemilu yang berbunyi one man one vote yang berarti setiap orang memiliki hak bersuara dan suara tersebut setara dengan suara orang lain. Hal ini tercermin dalam perilaku kehidupan masyarakat suku Tenger yang dibuktikan dengan proses pengangkatan dukun adat menjadi ketua adat.

Nilai-nilai demokrasi yang ada dalam masyarakat Tengger diterapkan dalam prosesi pengajuan dukun adat. Dalam hal ini pengajuan dan pemilihan dukun adat didasarkan pada adanya musyawarah untuk mufakat, kebebasan dalam berpendapat, menghargai pendapat sesama, dan sikap saling percaya diantara mereka. Keterlibatan masyarakat Tengger dalam proses musyawarah penentuan dukun adat ini dipimpin oleh dukun adat, dan difasilitasi oleh pemerintah desa setempat. Segala aspirasi dan saran yang diinginkan oleh masyarakat tengger ini nantinya akan diakomodir oleh dukun adat untuk dibawa dan dibahas dalam Parumun dukun. Hal ini dilakukan agar dijadikan dasar dalam pengambilan kebijakan oleh kepala adat suku Tengger.

Berdasarkan penjelasan Max Weber mengenai elit, peneliti membagi elit-elit suku Tengger di Argosari menjadi tiga tipe hubungan otoritas elite:

1. Elite otoritas tradisional dimana Pak Karyoleh sebagai elite tradisional yang dipilih berdasarkan aspek budaya di Suku Tengger melalui musyawarah dan ritual adat. Pola perilaku dan kepribadianya dihormati, dan dipatuhi oleh masyarakat akibat dari kekuasaan yang ada pada dirinya. Pak Karyoleh dalam teori elite menurut Max Weber termasuk dalam tipe elite tradisional, dimana beliau memiliki kekuasaan pula dalam merumuskan kebijakan yang dibuat oleh kepala desa. Dalam hal ini adat atau suku beserta aturanya dipandang lebih tinggi oleh masyarakat sehingga tetua dan sesepuhnya memiliki peranan yang kaut pula dalam masyarakat, walaupun tetua-tetua ini tidak memiliki jabatan formal dan tidak sedang memerintah,

2. Tipe otoritas kharismatik yang diduki oleh Pak Sandoyo dan Pak Repin yang merupakan tokoh masyarakat dari jalur keagamaan, mendapatkan posisi dan otoritas dari masyarakat dari pendalama sekotor keagamaan Pendapat dan arahan beliau didengarkan dan dipandang sebagai acuan dalam tindakanya. Mereka juga cenderung kuat dalam mempengaruhi kebijakan yang ada. Adapun kebijakan yang dibuat oleh governing elite setempat kiranya membutuhkan bantuan berupa saran dan masukan dari mereka (Pak Repin dan Pak Sandoyo).

3. Tipe otoritas legal formal yang mencakup pemangku kebijakan dalam posisi formal dan dipilih secara formal berkala 6 tahun sekali sesuai dengan aturan undang-undang yang berlaku. Otoritas tipe ini berkuasa atas dasar wewenang serta hak dan kewajibanya yang telah diatur dalam peraturan tettulis pemerintah secara sah. Pak Ismail selalku kepala desa setempat sangat dihargai dan s=disegani akibat dari jati diri serta jabatan yang melekat padanya. 
Sesuai dengan konspe kekuasaan tradisional jawa, Pak Karyoleh selaku dukun adat suku Tengger memiliki pengaruh yang cukup besar dalam masyarakat, hal ini dibuktikan dengan adanya beberapa temuan dilapangan yang menurut beberapa masyarakat, tokoh agama, serta para pelaku ekonomi (pengusaha) yang tunduk dan patuh atas perintah dukun adat. Dari segi keritualan, sosial dan budaya, juga dalam hal kebijakan kaitanya proses bermasyarakat. Hal ini sesuai dengan teori kekuasaan tradisional jawa oleh Mirriam Budiarjo dimana seseorang memiliki kekuasaan setidaknya ada dua bentuk, yang pertama memiliki modal sosial dan yang kedua memiliki modal ekonomi. Dalam hal ini pak Karyoleh memiliki modal ekonomi.

Terkait dengan konspe Partikulerisme Historis, pemilu pada tahun 2019 yang dilaksanakan di Desa Argosari, setidaknya menggambarkan sebuah pesta demokrasi yang unik. Pemilu yang pada umumnya diwarnai dengan gesekan pada lapisan masyarakat tertentu guna mengusung salah satu kandidat calon yang didukung, justru berbeda kondisi dengan Pemilu di Suku Tengger yang senantiasa terhindar dari gesekan antar warga setempat. Hal ini dibuktikan dengan keterangan dari dukun adat serta kepala desa setempat yang menyebutkan bahwasanya setiap datangnya pemilu masyarakat suku Tengger dan menyambut dengan gembira. Tidak ada konflik yang meruncung, serta segala bentuk politik yang ada berjalan sesuai koridor.

Berdasarkan hasil Pemilu di daerah Suku Tengger bermukim, PKB dalam hal ini merupakan partai dengan perolehan suara besar diikuti oleh PDIP yang membayanginya.

Sesuai dengan analisis teori partikulerisme historis menurut Hefner dimana dalam teori tersebut menjelaskan tentang seseorang atau masyrakat yang mengidentifikasi proses-proses historis yang bertanggung jawab bagi perkembangan kebudayaan-kebudayaan tertentu, dan pernyataan yang dilontarkan oleh dukun adat terkait pemilu, masyarakat suku Tengger cenderung nurut dan patuh terhadap masyarakat, hal ini disinyalir merupakan salah satu bentuk trauma yang terjadi saat tahun 1965 dimana terjadi perholakan politik antara NU yang membersamai pemerintah, dengan PKI dan PNI yang ada di daerah tersebut. Beberapa dari suku Tengger atas banyak yang di culik oleh kalangan NU dan pulang hanya tinggal nama dan kaos yang dikenakan terkahir kali. Hal ini menyebabkan trauma tersendiri bagi masyarakat Tenger hingga saat ini, sehingga apapun perintah dan arahan pemerintah serta siapapun penguasa yang sedang menjabat, Suku Tengger dalam hal ini patuh dan cenderung mengikuti alurnya.

\section{SIMPULAN}

Peran elit masyarakat Tengger dalam pemilu 2019 di Desa Argosari lalu, adalah sebuah salah satu miniatur tentang heterogonitas masyarakat yang telah mampu berdemokrasi secara dewasa dan dalam bingkai toleransi yang cukup hangat. Tingkat partisipasi yang ada dalam masyarakat dalam mengikuti acara pemilu yang tinggi ini disebabkan oleh gencarnya penyuluhan dan sosilisasi oleh para elit serta lembaga-lembaga terkait sepeti Kpu. Sinkronasi antara seluruh lapisan masyarakat dan elit yang ada membuat kehidupan daerah tersebut jauh dari konflik. Pemilu yang dilaksanakan pada tahun 
2019 lalu merupakan salah satu bukti tentang adanya partikulerisme historis dalam masyarakat, yang mana dalam menentukan pilihan serta calon yang ada masih terdapat bayangan tentang siapa yang memerintah saat ini. Hal tersebut dibuktikan dengan adanya perolehan suara PDIP dan PKB yang cukup signifikan sehingga kalkulasi dua partai tersebut bilamana ditotal mencapai hampir $60 \%$ hanya di desa tersebut saja. Terkait adanya sejarah penumpasan PKI dan afiliasi PNI yang diserbu oleh barisan NU dan pemerintah ini menjadi cikal bakal besarnya massa di daerah tersebut yang menganut aliran Islam NU. terkait beberapa elite yang ada, dari unsur formal maupun informal, masyarakat suku Tengger lebih dominan mempercayai elit informal seperti dukun adat ketimbang kepala desa yang secara formal jelas dan telah diatur oleh Undang-undang yang ada. Hal ini tidak terlepas dari kekuasaan tradisional yang mengikat dalam tubuh dukun adat yang didapatkannya melalui keturunan leluhur.

\section{DAFTAR PUSTAKA}

Budiarjo M (1984) Aneka Pemikiran tentang Kuasa dan Wibawa. Jakarta: Sinar Harapan.

Chalik A (2017) Dinamika Elite dalam Politik Lokal. Yogyakarta: Pustaka Pelajar.

Febrianto V (2019) Filosofi Masyarakat Tengger untuk Pemilu, Antara News, 23 Maret. Diakses 12 Oktober 2019, dari https://www.antaranews.com/berita/814433/filosofi-masyarakat-tenggeruntuk-pemilu

Fuad M (2014) Kyai di Panggung Pemilu dari Kyai Khos sampai High Cost. Jakarta: Renebook.

Harrison L (2007) Metodologi Penelitian Politik Jakarta: Preneda Media Grup.

Hefner RW (1999) Geger Tengger: Perubahan Sosial dan Perkelaian Politik.Yogyakarta: LKiS.

Komisi Pemilihan Umum (2019) Rekapitulasi Hasil Pemilu Legislatif DPRD Kab/Kota 2019. Diakses Oktober 2019, dari https://pemilu2019.kpu.go.id/\#/dprdkab/rekapitulasi/terkait-perolehan-suarakecamatan-senduro-kabupaten-lumajang

Legg KR (1982) Tuan, Hamba, dan Politisi. Jakarta: Yayasan Obor Jakarta.

Muhyidin A (2016) Aktor Politik dan Kepentingan. Jurnal Politik, 2(1), 1-4).

Nurhasim M ( 2005) Konflik antar Elite Politik Lokal Dalam Pemilihan Kepala Daerah. Yogyakarta: Pustaka Pelajar Offset.

Santosa S (1992) Dinamika Kelompok. Jakarta: Bumi Aksara.

Sugiyono (2016) Metode Penelitian Kuantitatif, Kualitatif dan R\&D. Bandung: PT. Alfabhet.

Surbakti R (2010) Memahami Ilmu Politik. Jakarta: Kompas Gramedia.

Semiawan C (2010) Metode Penelitian Kualitatif (Jenis, Karakteristik, dan Keunggulannya). Jakarta: Grasindo.

Wakhid AA (2011) Eksistensi Konsep Birokrasi Weber dalam reformasi Birokrasi Indonesia. TAPIs, 7(13), 126-146. 